\title{
Problems Faced By Rural Entrepreneurs and Remedies to Solve It
}

\author{
Sandeep Saxena \\ (M.B.A., Gautam Budha Technical University, Lucknow, India)
}

\begin{abstract}
India lives in its villages, nearly $73 \%$ of the total population live in rural areas where agriculture and allied activities are the main stay of their lives. The economic development of our country largely depends on the development of rural areas and the standard of living of its rural mass. Rural entrepreneur is one of the most important inputs in the economic development of a country and of regions within the country. Rural entrepreneur uses the scarce resources in the most efficient manner thereby increasing profits and decreasing costs. Due to lack of education, majority of rural people are unaware of technological development, marketing etc. Shortage of finance and raw materials are main problems face by rural entrepreneurs. Most of the rural entrepreneurs face peculiar problems like illiteracy, fear of risk, lack of training and experience, limited purchasing power and competition from urban entrepreneurs. Promotion of rural entrepreneurship is a key to develop rural areas and backward towns. This paper focuses on the identification of various problems associated with rural entrepreneurship. Suitable cures have also been discussed to overcome these problems.
\end{abstract}

Key words: Economic development, Lack of training, Purchasing power, Rural entrepreneur, Rural mass.

\section{Introduction}

After over 5 decades of Independence and Industrialization in our country, still large part of population remains under poverty line. Agriculture continues to be the back bone of rural society. As per this study, 70 per cent of holdings are held by small and marginal farmers resulting in overcrowding on the agricultural land and diminishing farm produce. This also results in migration of farm worker in large numbers to the urban areas. In both the cases the population remains under poverty line. Entrepreneurship can play an important role in rural development. "Entrepreneur means one who creates a product on his own account, who ever undertakes on his own an industrial/trading enterprise in which work men are employed". If entrepreneurships really encouraged in rural area it would, of course, be instrumental in changing the face of rural areas by solving the problems of unemployment, poverty, economic disparity, poor utilization of rural capacity, low level of standard of living .Majority of the population still lives in rural India and the large chunk of population in urban areas still live through the learning of a village life. For the strength of the country there is a necessity to develop the villages. Development of a country is a choice loaded on its people, whether urban or rural. It is individuals who shape up a society and decide its progress and performance. Urban and rural are two sides of the same coin of economic development. While the urban sector has witnessed phenomenal growth and development, fuelled by the post independence era of industrialization, the rural sector saw little corporate growth.

Rural development is more than ever before linked to entrepreneurship. Institutions and individuals promoting rural development now see entrepreneurship as a strategic development intervention that could accelerate the rural development process. Furthermore, institutions and individuals seem to agree on urgent need to promote rural enterprises.

\section{Rural Entrepreneurship And Development Of Villages}

Rural entrepreneurship implies entrepreneurship emerging in rural areas. In other words establishing industries in rural areas refers to rural entrepreneurship. This means rural entrepreneurship is synonymous with rural industrialization. Many examples of successful rural entrepreneurship can already be found in literature. Diversification into non-agricultural uses of available resources such as catering for tourists, blacksmithing, carpentry, spinning, etc. as well as diversification into activities other than those solely related to agricultural usage, for example, the use of resources other than land such as water, woodlands, buildings, available skills and local features, all fit into rural entrepreneurship. The entrepreneurial combinations of these resources are, for example: tourism, sport and recreation facilities, professional and technical training, retailing and wholesaling, industrial applications (engineering, crafts), servicing (consultancy), value added (products from meat, milk, wood, etc.) and the possibility of off-farm work. Equally entrepreneurial, are new uses of land that enable a reduction in the intensity of agricultural production, for example, organic production.

[A] Better distribution of farm produce resulting in the rural prosperity.

[B] Entrepreneurial occupation rural for youth resulting in reduction of disguised employment and alternative occupations for rural youth. 
[C] Formations of big cooperatives like Amul for optimum utilization of farm produce.

[D] Optimum utilization of local resource in entrepreneurial venture by rural youth.

Indian agriculture is characterized by low productivity, exposure for vagaries of nature like drought, flood, other natural disasters and weaknesses like mismatch between agricultural and cash crops, inadequate infrastructure to provide for value addition, wide disparity in public-private partnership in agricultural development.

Land being limited is unable to absorb the entire labour force throughout the year leading to large scale unemployment and underemployment.

Rural people, in search of jobs, often migrate to urban centre's creating unwanted slums and live in unhygienic conditions of living.

A turnaround is possible in the above trend if employment opportunities are made available in rural areas along with basis amenities of life. The real solution to India's economic problem is not mass production but production by masses as was suggested by Mahatma Gandhi.

Rural industrialization through the development of rural entrepreneur seems to be the answer to poverty, unemployment and back-wardens of Indian economy.

Government of India in its successive five year plans has been assigning increasing importance and support for the promotion and development of rural entrepreneurship.

Rural entrepreneurship is a process which introduces new things in the economy. Rural entrepreneurship is the attempt to create value though recognition of business opportunity, the management of risk-taking appropriate to the opportunity, and through the communicative and management skills to mobilize human, financial and material resources necessary to bring a project to fruition in rural areas. The role of entrepreneurship was recognized in India much earlier than other countries. After Independence, with the advent of planning and even after the completion of First Plan, a new enthusiasm was on the scene. Young men instead of going for higher studies in law or literature turned to Science and Technology. The number of applications for industrial licenses to set-up new projects shot-up and there was keen competition among intending entrepreneurs. Most of the total population live in rural areas.

Balanced development is the need of hour and it is possible only when rural areas will flourish. Growth of rural entrepreneurship may lead to reduction in poverty, growth of slums, pollution in cities and ignorance of inhabitants. It helps in improving standard of living and literacy rate of rural people. Rural industries include traditional sector and modern sector. Former consists of khadi and village industries, handloom, sericulture, handicraft and coir while the latter include power looms and small scale industries.

\section{Objective Of Study}

- To analyze the problems faced in growth of rural entrepreneurs in India.

- To find out the remedies to solve the problems of rural entrepreneurs.

\section{Five Measures For Development Of Rural Entrepreneurs In India}

Entrepreneurs emerging in rural areas are generally termed as rural entrepreneurs. These types of entrepreneurs give much emphasis on establishment of industrial units in rural areas. Rural entrepreneurs have paid special attention on village industries which are classified into the following major categories.

- Agro-based Industry

- Textile Industry

- Polymer and chemical based Industry

- Engineering Industry

There is a growing need for rural entrepreneurs because industrial units undertaken by rural entrepreneurs are providing much employment to men than machines. It has high potential for income generation in rural areas because of more employment opportunities.

It also facilitates wide dispersal of economic activities in rural areas. In spite of growing need for rural entrepreneurs, there has not been much progress and development of rural entrepreneurs. Slow progress of rural entrepreneurs is seen from the following data.

The analysis of above data reveals that there is no much substantial development of rural entrepreneurs and rural industries in different plan period.

However, the growth of rural entrepreneurs in 2nd five year plan is quite satisfactory. As growth of rural entrepreneurs is not satisfactory, the following measures are to be implemented for development of rural entrepreneurs.

i. As raw materials constitute the basic ingredient of industry, there should be free and continuous supply of raw materials. Continuous supply of raw materials ensures continuous and smooth production process.

ii. Rural entrepreneurs face inadequacy of capital which is regarded as the life blood of business unit. Provision for adequate capital will facilitate development of rural entrepreneurs. 
iii. One of the major problems of rural entrepreneurs is marketing of product. The problems of marketing can be solved by provision of common production cum marketing centres.

iv. Most of rural entrepreneurs accept this professional career not according to their choice but by chance. This ensures lack of aptitude and competency. One can overcome these difficulties by encouraging rural entrepreneurs.

v. Rural industries fail not due to non-availability of facilities but non-awareness of facilities. In the present days different non-government organizations (NGOs) are formed for developing awareness programmed on development of entrepreneurs. There are 3 different types of NGOs.

vi. Primary level NGOs who mobilize their own resources. They operate at international level for undertaking developmental activities. The examples of these types of NGOs are ACTION AID and OXFAM.

Vii. Intermediate NGOs who obtains funds from various agencies. They conduct different training programmers and workshop. The examples of intermediate NGOs are SEWA and AWAKE.

viii. Grass root levels NGOs denote a type of NGO which conduct field activities by establishing linkage with grass root people. RUDSETI and ANARDE are the best examples of grass root level NGO.

\section{Roles Of Rural Entrepreneurs In Economic Development}

The entrepreneurs with their ability to scan, analyze and identify opportunities in the environment transform them into business proposition through creation of economic entities.

They by channelizing the resources from less productive to move productive use crate wealth. Through efficient and effective utilization of national resources, they act as catalysts for economic development and agents of social transformation and change.

According to Joseph Schumpeter, the rate of economic progress of a nation depends upon its rate of innovation which is turn depends on rate of increase in the entrepreneurial talent in the population.

According to Meir and Baldwin, development does not occur spontaneously as a natural consequence when economic conditions in some sense are right.

A catalyst is needed which results in entrepreneurial activity to a considerable extent. The diversity of activities that characterizes rich countries can be attributed to the supply of entrepreneurs. They play a vital role for the economic development of a country in the following ways.

\subsection{Formation of Capital}

Entrepreneurs by placing profitable business proposition attract investment to ensure private participation in the industrialization process.

The otherwise idle savings are channelized for investment in business ventures which in turn provides return. Again the savings are invested giving a multiplier effect to the process of capital formation.

\subsection{Balanced Regional Development}

The entrepreneurs always look for opportunities in the environment. They capitalize on the opportunities of governmental concessions, subsidies and facilities to set up their enterprises in undeveloped areas.The setting up of still plant at Tata nagar, Reliance Petrochemicals at Jamnagar (Gujarat) have resulted in the development of Good Township and peripheral regional development. Thus entrepreneurs reduce the imbalances and disparities in development among regions.

\subsection{General Employment}

This is the real charm of being an entrepreneur. They are not the job seekers but job creators and job providers. With the globalization process the government jobs are shrinking leaving many unemployed.

In the circumstances, the entrepreneurs and their enterprises are the only hope and source of direct and indirect employment generation.

Employment is generated directly by the requirement of the large enterprises and indirectly by ancilliariation and consequential development activities.

\subsection{Improvement in Standard of Living}

Entrepreneurial initiative through employment generation leads to increase in income and purchasing power which is spent on consumption expenditure. Increased demand for goods and services boost up industrial activity.

Large scale production will result in economies of scale and low cost of production. Modern concept of marketing involves creating a demand and then filling it.

New innovative and varying quality products at most competitive prices making common man's life smoother, easier and comfortable are the contribution of entrepreneurial initiative. 


\subsection{Increase in per Capita Income}

Entrepreneurs convert the latent and idle resources like land, labour and capital into goods and services resulting in increase in the national income and wealth of a nation.

The increase in national income is the indication of increase in net national product and per capita income of the country.

\subsection{National Self-reliance}

Entrepreneurs are the corner stores of national self-reliance. They help to manufacture indigenous substitutes to imported products which reduce the dependence on foreign countries.

There is also a possibility of exporting goods and services to earn foreign exchange for the country. Hence, the import substitution and export promotion ensure economic independence and the country becomes self-reliance.

\subsection{Planned Production}

Entrepreneurs are considered as economic agents since they unite all means of production. All the factors of production i.e., land, labour, Capital and enterprise are brought together to get the desired production. This will help to make use all the factors of production with proper judgment, perseverance and knowledge of the world of business. The least combination of factors is possible avoiding unnecessary wastages of resources.

\subsection{Equitable Distribution Economic Power}

The modern world is dominated by economic power. Economic power is the natural outcome of industrial and business activity. Industrial development may lead to concentration of economic power in few hands which results in the growth of monopolies.

The increasing number of entrepreneurs helps in dispersal of economic power into the hands of many efficient managers of new enterprises. Hence setting up of a large number of enterprises helps in weakening the evil effects of monopolies.

Thus, the entrepreneurs are key to the creation of new enterprises that energies the economy and rejuvenate the established enterprises that make up the economic structure.

\subsection{Provide employment opportunities}

\section{Benefits From Rural Entrepreneurship}

Rural entrepreneurship is labor intensive and provides a clear solution to the growing problem of unemployment. Development of industrial units in rural areas through rural entrepreneurship has high potential for employment generation and income creation.

\subsection{Check on migration of rural population}

Rural entrepreneurship can fill the big gap and disparities in income rural and urban people. Rural entrepreneurship will bring in or develop infrastructural facilities like power, roads, bridges etc. It can help to check the migration of people from rural to urban areas in search of jobs.

\subsection{Balanced regional growth}

Rural entrepreneurship can dispel the concentration of industrial units in urban areas and promote regional development in a balanced way.

\subsection{Promotion of artistic activities}

The age-old rich heritage of rural India is preserved by protecting and promoting art and handicrafts through rural entrepreneurship.

\subsection{Check on social evils}

The growth of rural entrepreneurship can reduce the social evils like poverty, growth of slums, pollution in cities etc.

\subsection{Awaken the rural youth}

Rural entrepreneurship can awaken the rural youth and expose them to various avenues to adopt entrepreneurship and promote it as a career.

\subsection{Improved standard of living}

Rural entrepreneurship will also increase the literacy rate of rural population. Their education and selfemployment will prosper the community, thus increasing their standard of living. 


\section{Problems In Rural Entrepreneurship}

Entrepreneurs are playing very important role in the development of economy. They face various problems in day to day work. As the thorns are part of roses, similarly every flourishing business has its own kind of problems. Some of the major problems faced by rural entrepreneurs are as under.

\subsection{FINANCIAL PROBLEMS}

\subsubsection{PAUCITY OF FUNDS}

Most of the rural entrepreneurs fail to get external funds due to absence of tangible security and credit in the market. The procedure to avail the loan facility is too time-consuming that its delay often disappoints the rural entrepreneurs.

Lack of finance available to rural entrepreneurs is one of the biggest problems which rural entrepreneur is bearing now days especially due to global recession. Major difficulties faced by rural entrepreneurs include low level of purchasing power of rural consumer so sales volume is insufficient, lack of finance to start business, reduced profits due to competition, pricing of goods and services, Financial statements are difficult to be maintained by rural entrepreneur, stringent tax laws, lack of guarantees for raising up of loans, difficulty in raising capital through equity, dependence on small money lenders for loans for which they charge discriminating interest rates and huge rent and property cost.

These all problems create a difficulty in raising money through loans. landlords in Punjab proved to be major source of finance for rural entrepreneurs but the rates of land are reduced due to global recession so they also lack hard cash now a days. Some banks have not ventured out to serve rural customers because banks are expensive to be reached by rural customers and, once reached, are often too poor to afford bank products. Poor people often have insufficient established forms of collateral (such as physical assets) to offer, so they are often excluded from traditional financial market. Government is providing subsidies to rural areas but due to high cost of finance, these subsidies are not giving fruitful results.

Major sources of finance in rural areas are loans from regional rural banks or from zamindars but their rate of interest are usually very high. Government has various institutions for this purpose but the results are not up to the level expected. Industrial Finance Corporation of India (IFCI), Industrial development bank of India, Industrial Credit and Investment Corporation of India (ICICI), Small Scale Industry development bank of India (SIDBI) are some of the national level (SFC) institutions that are helping out rural entrepreneurs. Some state level institutions are also working like State Financial Corporation and State Industrial Development Corporation (SIDC). These institutions are providing assistance for setting up of new ventures and side by side for modernization and expansion of existing ones but their terms and conditions are very strict to be handled.

Various schemes like composite loan scheme, tiny unit scheme, scheme for technical entrepreneurs etc. had started but they are unable to meet the expectation of rural entrepreneur. Raising funds through equity is little bit difficult for rural entrepreneurs because of lack of financial knowledge and also their financial corpus is also low, so loans are primary source of finance for them which proved to be a greatest obstacle in developing rural entrepreneurship. Various policies of RBI regarding priority sector lending failed to achieve its objectives. Micro financing movements started in India worked well. Self help groups form the basic constituent unit of micro finance movement in India. Self help groups are a group of a few individuals who pool their savings into a fund from which they can borrow as and when necessary. Such a group is linked with banks but joining an existing SHG is often costly affair for an aspiring villager as in order to maintain parity among the members, a new member has to join by depositing the total accumulated individual savings and interest of groups. So starting new SHG is an easy as compared to join existing one. NGO's also played important role for rural development. These NGO's are usually registered as societies and trust. They have less capital resources as they cannot raise equity capital.

\subsubsection{LACK OF INFRASTRUCTURAL FACILITIES}

The growth of rural entrepreneurs is not very healthy in spite of efforts made by government due to lack of proper and adequate infrastructural facilities.

\subsubsection{RISK ELEMENT}

Rural entrepreneurs have less risk bearing capacity due to lack of financial resources and external support.

\subsection{MARKETING PROBLEMS}

\subsubsection{COMPETITION}

Rural entrepreneurs face severe completion from large sized organizations and urban entrepreneurs. They incur high cost of production due to high input cost. Major problems faced by marketers are the problem of standardization and competition from large scale units. They face the problem in fixing the standards and sticking to them. Competition from large scale units also creates difficulty for the survival of new ventures. New ventures have limited financial resources and hence cannot afford to spend more on sales promotion. These units are not having any standard brand name under which they can sell their products. New ventures have to come up with new advertisement strategies which the rural people can easily understand. The literacy rate among the 
rural consumer is very low. Printed media have limited scope in the rural context. The traditionally bounded nature, cultural backwardness and cultural barriers add to the difficulty of communication. People in rural areas mostly communicate in their local dialects and English and Hindi are not understood by many people. It has been seen in recent past that in spite of enough food stocks with government warehouses, people are dying of starvation. This indicates problem with the public distribution system. The producers are not collective in their approach for marketing their products because they are to widely scattered and uneducated.

7.2.2 MIDDLEMEN

Middlemen exploit rural entrepreneurs. The rural entrepreneurs are heavily dependent on middlemen for marketing of their products who pocket large amount of profit. Storage facilities and poor means of transport are other marketing problems in rural areas. In most of the villages, farmers store the produce in open space, in bags or earthier vessels etc. So these indigenous methods of storage are not capable of protecting the produce from dampness, weevils etc. The agricultural goods are not standardized and graded.

\subsection{MANAGEMENT PROBLEMS}

\subsubsection{LAKE OF KNOWLEDGE OF I.T}

Information technology is not very common in rural areas. Entrepreneurs rely on internal linkages that encourage the flow of goods, services, information and ideas. The intensity of family and personal relationships in rural communities can sometime be helpful but they may also present obstacles to effective business relationships. Business deals may receive less than rigorous objectivity and intercommunity rivalries may reduce the scope for regional cooperation. Decision making process and lines of authority are mostly blurred by local politics in rural areas.

\subsubsection{LEGAL FORMALITIES}

Rural entrepreneurs find it extremely difficult in complying with various legal formalities in obtaining licenses due to illiteracy and ignorance.

\subsubsection{PROCUREMENT OF RAW MATERIALS}

Procurement of raw materials is really a tough task for rural entrepreneur. They may end up with poor quality raw materials, may also face the problem of storage and warehousing.

\subsubsection{LACK OF TECHNICAL KNOWLEDGE}

Rural entrepreneurs suffer a severe problem of lack of technical knowledge. Lack of training facilities and extension services crate a hurdle for the development of rural entrepreneurship.

7.3.5 POOR QUALITY OF PRODUCTS

Another important problem is growth of rural entrepreneurship is the inferior quality of products produced due to lack of availability of standard tools and equipment and poor quality of raw materials.

\subsection{HUMAN RESOURCES PROBLEMS}

\subsubsection{LOW SKILL LEVEL OF WORKERS}

Most of the entrepreneurs of rural areas are unable to find workers with high skills. Turnover rates are also high in this case. They have to be provided with on the job training and their training is generally a serious problem for entrepreneur as they are mostly uneducated and they have to be taught in local language which they understand easily. The industries in rural areas are not only established just to take advantage of cheap labour but also to bring about an integrated rural development. So rural entrepreneurs should not look at rural area as their market, they should also see the challenges existing in urban areas and be prepared for them. Rural entrepreneurs are generally less innovative in their thinking. Youths in rural areas have little options "this is what they are given to believe". This is the reason that many of them either work at farm or migrate to urban land.

\subsubsection{NEGATIVE ATTITUDE}

The environment in the family, society and support system is not conducive to encourage rural people to take up entrepreneurship as a career. It may be due to lack of awareness and knowledge of entrepreneurial opportunities. The young and well educated mostly tend to leave. As per circumstances, rural people by force may be more self sufficient than their urban counterparts, but the culture of entrepreneurship tends to be weak. Continuous motivation is needed in case of rural employee which is sometime difficult for an entrepreneur to impart with.

\section{Remidies To Solve These Problems}

Different organization like IFCI, ICICI, SIDBI, NABARD etc. are trying to sort these problems. Marketing problems are related with distribution channels, pricing, product promotion etc. In order to make the rural entrepreneurs to stat the business venture, the following measures may be adopted:

\subsection{Creation of finance cells}

The financial institutions and banks which provide finances to entrepreneurs must create special cells for providing easy finance to rural entrepreneurs. 


\subsection{Concessional rates if interest}

The rural entrepreneurs should be provided finance at concessional rates of interest and on easy repayment basils. The cumbersome formalities should be avoided in sanctioning the loans to rural entrepreneurs. 8.3 Proper supply of raw materials

Rural entrepreneurs should be ensured of proper supply of scarce raw materials on priority basis. A subsidy may also be offered to make the products manufactured by rural entrepreneurs cost competitive and reasonable.

\subsection{Offering training facilities}

Training is essential for the development of entrepreneurships. It enables the rural entrepreneurs to undertake the venture successfully as it imparts required skills to run the enterprise.

Presently the economically weaker entrepreneurs of the society are offered such training facility under Prime Minister's Rozgar Yojna. (PMRY) Programmed FICCI, (NGOs) Lions Clubs, Rotary Clubs and voluntary organizations can also arrange such training programmers for rural entrepreneurs to provide them stimulation counseling and assistance .For rural entrepreneurs, individual based EDI' approach is highly relevant where the motivation and familiarization processes coupled with promise of bank credit and support by way of escort services could persuade rural youth with certain basic skills of- hands on technology to start small enterprises.

\subsection{Setting up marketing co-operatives}

Proper encouragement and assistance should be provided to rural entrepreneurs for setting up marketing co-operatives. These co-operatives shall help in getting the inputs at reasonable rate and they are helpful in selling their products at remuneration prices.

Hence, middlemen can be avoided and rural entrepreneurs derive the benefits of enterprise. Common production-cum-marketing centers should be set up with modern infrastructural facilities.

Thus, proper education, comprehensive training, setting up of separate financial institutions, development of marketing co-operatives to a large extent help to flourish the rural entrepreneurs in India. Further, both government and non-government agencies should play an important role.

\section{Suggestions}

1. Govt. should provide separate financial fund of rural entrepreneur.

2. We should provide special infrastructure facilities whatever they deed.

3. Govt. should arrange special training programmes of rural entrepreneurship

4. Govt. should felicitate top ranker rural's entrepreneur.

5. Rural entrepreneur should more competitive and efficient in the local \& international market.

6. Use should invite successful rural entrepreneurs from other states of country.

\section{Conclusions}

Rural entrepreneur is a key figure in economic progress of India. Rural entrepreneurship is the way of converting developing country into developed nation. Rural entrepreneurship is the answer to removal of rural poverty in India. Therefore, there should be more stress on integrated rural development programs. The problem is that most of the rural youth do not think of entrepreneurship as the career option. Therefore, the rural youth need to be motivated to take up entrepreneurship as a career, with training and sustaining support systems providing all necessary assistance. There should be efficient regulated market and government should also lend its helping hand in this context. Grading and standardization should be promoted and promotional activities should be enhanced. NGO's should be provided full support by government.

\section{Journal Papers}

\section{References}

[1] Power, Thomas Michael Lost Landscapes and Failed Economies: The Search for A Value of Place, Island Press, 1996, 38.

[2] Regional Technology Strategies, Inc Evaluation of the ARC's Entrepreneurship Initiative, February $2001,1$.

[3] Rural Policy Research Institute (RUPRI) Opportunities for Rural Policy Reform: Lessons Learned from Recent Farm Bills, $1995,2$.

[4] Zacharis, Andrew L., William D., By grave, and Dean A. Shepherd. 2000. Global Entrepreneurship Monitor: National Entrepreneurship. Assessment, United States, Executive Report, Kauffman Center for Entrepreneurial Leadership at the Ewing Marion Kauffman Foundation, 2000, 3.

[5] C. H. Gladwin, B. F. Long, E. M. Babb, L. J.Beaulieu, A. Moseley, D. Mulkey and D. J. Zimet(1989), Rural Entrepreneurship: One Key to Rural Revitalization American Journal of Agricultural Economics, Vol. 71, No. 5, 130. 